\title{
Pola Luka pada Korban Meninggal akibat Kekerasan Tumpul yang Diautopsi di RSUP Prof. Dr. R. D. Kandou Manado Periode Januari-Desember 2014
}

\author{
${ }^{1}$ Zari Enma P. S. \\ ${ }^{2}$ Erwin Kristanto \\ ${ }^{2}$ James F. Siwu
}

\author{
${ }^{1}$ Program Studi Pendidikan Dokter Fakultas Kedokteran Universitas Sam Ratulangi Manado \\ ${ }^{2}$ Bagian Ilmu Kedokteran Forensik Medikolegal Fakultas Kedokteran \\ Universitas Sam Ratulangi Manado \\ Email: zarienma16@gmail.com
}

\begin{abstract}
This study was aimed to determine the injury patterns of victims died due to blunt violence and were autopsied at Prof. Dr. R. D. Kandou Hospital Manado from January December 2014. This was a descriptive and retrospective study using medical record data of Forensic and Medicolegal Department, Medical Faculty of Sam Ratulangi University/Prof. Dr. R. D. Kandou Hospital Manado during the period from January 2014 to December 2014. The results showed that during that period there were 13 deaths due to blunt violence that met the criteria. There were twelve male and and one female victims. Further studies with longer periods of time involving other hospitals around Manado are needed.
\end{abstract}

Keywords: patterns of wound, blunt trauma, dead victim

\begin{abstract}
Abstrak: Penelitian ini bertujuan untuk mengetahui pola luka pada korban meninggal akibat kekerasan tumpul yang diautopsi di RSUP Prof. Dr. R.D. Kandou Manado periode Januari Desember 2014. Jenis penelitian ialah deskriptif dan retrospektif dengan menggunakan data rekam medik Bagian Ilmu Kedokteran Forensik Medikolegal FK Unsrat- RSUP Prof. Dr. R. D Kandou Manado selama periode Januari 2014 sampai dengan Desember 2014. Hasil penelitian menunjukkan bahwa selama periode tersebut terdapat 13 korban yang meninggal akibat kekerasan tumpul yang memenuhi kriteria. Terdapat 12 korban berjenis kelamin laki-laki dan satu korban berjenis kelamin perempuan. Disarankan penelitian lebih lanjut dengan periode pendlitian yang lebih panjang dengan melibatkan rumah sakit lainnya di sekitar Manado.
\end{abstract}

Kata kunci: pola luka, trauma tumpul, korban mati

Kekerasan adalah perbuatan yang dapat berupa fisik maupun non fisik dengan cara pasif (tidak berbuat) dan ada akibat yang merugikan korban. ${ }^{1}$

Luka mungkin diderita oleh korban atau pelaku yang merupakan hasil dari tindakan yang disengaja maupun tidak sengaja. Luka tergantung pada keparahannya dan luasnya. Analisis pola luka meliputi pengenalan, pemeliharaan, dan dokumentasi. Analisis pola luka merupakan hal yang sangat penting serta dapat berperan investigatif dan rekonstruksi dari kasus pembunuhan, pemerkosaan, penyiksaan, dan tindakan kekerasan interpersonal lainnya. Luka yang disebabkan oleh benda yang berujung runcing dan bermata tajam yaitu luka tusuk, luka iris, luka bacok sedangkan luka yang disebabkan oleh benda yang berujung tumpul seperti batu, besi, tinju, dan lain-lain. ${ }^{1,2}$

Sebagaimana diketahui bahwa kejahatan yang terjadi dimuka bumi ini sama usia tuanya dengan sejarah manusia sendiri. 
Luka merupakan salah satu kasus tersering dalam Kedokteran Forensik. Kekerasan biasa berupa tindakan kekerasan fisik atau kekerasan psikologi. Ada kekerasan dalam rumah tangga, kekerasan terhadap anak, kekerasan seksual dan sebagainya. Dokter yang bekerja di Indonesia perlu memahami Ilmu kedokteran Forensik termasuk cara membuat Visum et Repertum., ${ }^{2,3}$

Seorang dokter perlu menguasai pengetahuan tentang mendeskripsikan luka, dengan tujuan untuk mempermudah tugastugasnya dalam membuat Visum et Repertum yang baik dan benar sehingga dapat digunakan sebagai alat bukti yang bisa menyakinkan hakim untuk memutuskan suatu tindak pidana. Pada kenyataannya dalam praktek, dokter sering mengalami kesulitan dalam membuat Visum et Repertum karena kurangnya pengetahuan tentang luka. ${ }^{2}$

Tujuan pemeriksaan kedokteran forensik pada korban hidup ialah untuk mengetahui penyebab luka/sakit dan derajat parahnya luka atau sakitnya tersebut. Hal ini dimaksudkan untuk memenuhi rumusan delik dalam KUHP. Jelaslah di sini bahwa pemeriksaan kedokteran forensik tidak ditujukan untuk pengobatan. ${ }^{4}$

Terhadap setiap pasien, dokter harus membuat catatan medik atas semua hasil pemeriksaan mediknya. Pada korban yang diduga korban tindak pidana, pencatatan harus lengkap dan jelas sehingga dapat digunakan untuk pembuatan visum et repertum. Catatan medik yang tidak lengkap dapat mengakibatkan hilangnya sebagian barang bukti di dalam bagian pemberitaan visum et repertum. ${ }^{4,5}$

Benda-benda yang dapat mengakibatkan luka dengan sifat luka akibat kekerasan tumpul ialah benda yang memiliki permukaan tumpul. Luka yang terjadi dapat berupa memar (kontusio, hematom, luka lecet (ekskoriasi, abrasi) dan luka terbuka/ robek (vulnus laseratum). ${ }^{6}$ Memar adalah suatu perdarahan dalam jaringan bawah kulit akibat pecahnya kapiler dan vena, yang disebabkan oleh kekerasan benda tumpul. Luka memar kadangkala memberi petunjuk tentang bentuk benda penyebab- nya, misalnya jejas ban yang sebernarnya ialah suatu perdarahan tepi (marginal haemorrhage).

Letak, bentuk, dan luas luka memar dipengaruhi oleh berbagai faktor seperti besarnya kekerasan, jenis benda penyebab (karet, kayu, besi), kondisi dan jenis jaringan (jaringan ikat longgar, jaringan lemak), usia, jenis kelamin, corak dan warna kulit, serta kerapuhan pembuluh darah, penyakit (hipertensi, penyakit kardio vaskular, diathesis hemoragik). ${ }^{4,8}$ Pada bayi, hematom cenderung lebih mudah terjadi karena sifat kulit yang longgar dan masih tipisnya jaringan lemak subkutan, demikian pula pada usia lanjut sehubungan dengan menipisnya jaringan lemak subkutan dan pembuluh darah yang kurang terlindung. 4,9

Umur luka memar secara kasar dapat diperkirakan melalui perubahan warnanya. Pada saat timbul, memar berwarna merah, kemudian berubah menjadi ungu atau hitam, setelah 4 sampai 5 hari akan berwarna hijau yang kemudian akan berubah menjadi kuning dalam 7 sampai 10 hari, dan akhirnya menghilang dalam 14 sampai 15 hari. Perubahan warna tersebut berlangsung mulai dari tepi dan waktunya dapat bervariasi tergantung derajat dan berbagai faktor yang memengaruhinya. ${ }^{4,10}$

Penelitian ini bertujuan untuk mendapatkan pola luka pada korban meninggal akibat kekerasan tumpul yang diautopsi di RSUP Prof. Dr. R. D. Kandou Manado periode Januari - Desember 2014.

\section{METODE PENELITIAN}

Jenis penelitian ini ialah deskriptif retrospektif dengan menggunakan data sekunder di Bagian Ilmu Kedokteran Forensik Medikolegal FK Unsrat - RSUP Prof. Dr. R. D. Kandou Mando periode bulan Oktober - Desember 2015. Populasi target ialah kasus kekerasan tumpul yang mengakibatkan kematian di kota Manado.

Variabel penelitian yaitu jumlah kasus, jenis kelamin, usia, dan lokasi luka. Jumlah kasus ialah semua kejadian yang mengalami luka akibat kekerasan tumpul yang mengakibatkan kematian di Bagian Ilmu 
Kedokteran Forensik Medikolegal FK Unsrat. Pengambilan data penelitian di lakukan melalui surat keterangan Visum et Repertum.

\section{HASIL PENELITIAN}

Pada penelitian ini didapatkan 13 sampel dengan kematian akibat kekerasan tumpul di Bagian Ilmu Kedokteran Forensik Medikolegal FK Unsrat - RSUP Prof. Dr. R. D. Kandou Manado

Tabel 1. Jumlah kasus kematian akibat kekerasan tumpul selama periode Januari sampai Desember 2014 yang diperiksa menurut data Visum et Repertum (VeR) di Bagian Ilmu Kedokteran Forensik Medikolegal FK Unsrat RSUP Prof. Dr. R. D. Kandou Manado

\begin{tabular}{lcc}
\hline \multicolumn{1}{c}{ Bulan } & N & \% \\
\hline Januari & 1 & 7,69 \\
Februari & - & - \\
Maret & - & - \\
April & 1 & 7,69 \\
Mei & 2 & 15,38 \\
Juni & 1 & 7,69 \\
Juli & 2 & 15,38 \\
Agustus & 1 & 7,69 \\
September & - & - \\
Oktober & 1 & 7,69 \\
November & 2 & 15,38 \\
Desember & 2 & 15,38 \\
Jumlah & 13 & 100 \\
\hline
\end{tabular}

Keterangan: $\mathrm{n}=$ Jumlah sampel

\section{BAHASAN}

Visum et Repertum adalah keterangan yang dibuat oleh para dokter atas permintaan penyidik yang berwewenang mengenai hasil pemeriksaan medis terhadap manusia, baik hidup maupun mati. Visum et Repertum menguraikan segala sesuatu tentang hasil pemeriksaan medis. Pada surat permintaan harus jelas tertulis jenis pemeriksaan medis. ${ }^{1,2,11}$

Hasil penelitian ini mendapatkan 13 kasus kematian akibat kekerasan tumpul yang diautopsi selama periode Januari sampai Desember 2014 di Bagian Ilmu Kedokteran Forensik Medikolegal FK Unsrat - RSUP Prof. Dr. R. D. Kandou Manado. Jumlah kasus yang hanya sedikit dalam penelitian ini tidak dapat menggam- barkan jumlah kasus keseluruhan di Kota Manado apalagi di Provinsi Sulawesi Utara. Hal ini dapat terjadi karena banyak kasus lainnya yang tidak dibawa ke RSUP. Prof. Dr. R. D. Kandou Manado tetapi di dibawa ke rumah sakit lain atau jumlah kasus kekerasan tumpul di Manado yang di autopsi hanya sedikit di Kota Manado. Data sampel pada penelitian ini diambil dari hasil dan temuan visum 13 korban.

\section{SIMPULAN}

Berdasarkan hasil penelitian dapat disimpulkan bahwa selama periode Januari - Desember 2014 terdapat tiga belas kasus luka akibat kekerasan tumpul yang menyebabkan kematian di Bagian Ilmu Kedokteran Forensik Medikolegal FK Unsrat - RSUP Prof. Dr. R. D Kandou Manado.

\section{SARAN}

Perlu penelitian lebih lanjut dengan periode yang lebih panjang dengan mengikutsertakan rumah sakit lainnya yang ada di sekitar Kota Manado.

Perlu penelitian lebih lanjut dengan membandingkan kasus luka akibat kekerasan tumpul yang terdata di kantor kepolisian.

\section{DAFTAR PUSTAKA}

1. Pajraman. Catatan Kuliah Ilmu Kedokteran Forensik. Bandung: FK Universitas Padjajaran, 1990.

2. Idries AM. Pedoman Ilmu Kedokteran Forensik (1st ed). Jakarta: Binarupa Aksara, 1997.

3. Windi. Traumatologi forensik [online]. 2006 [cited 2014 Sep 18]. Available from: http://www.freewebs.com/traumatologi e2/traumatologi.htm.

4. Budiyanto A, Widiatmaka W, Sudiono S, Mun'im TWA, Sidhi, Hertian S, et al. Ilmu Kedokteran Forensik. Jakarta: Bagian Kedokteran Forensik Fakultas Kedokteran Universitas Indonesia, 1997.

5. Chapter 4 Utah Medical Examiner Act[online]. Utah, 2011 [cited 2014 Oct 03]. Available from: https://le.utah.gov/ xcode/Title26/Chapter4/C26-4_ 
1800010118000101.pdf

6. Idries AM, Tjiptomartono AL. Penerapan Ilmu Kedokteran Forensik dalam Proses Penyidikan (Edisi Revisi). Jakarta: Sagung Seto, 2008.

7. Varghese TK. Chest trauma. In: Mullohan et al, editors. Greenfield's Surgery. USA: Lippincot Wilkins, 2011.

8. Fischer AH. Gender and Emotions. Cambridge: Cambridge Universal Press, 2000.
9. Shkrum MJ, Ramsaytfd DA. Forensic Science and Medicine: Forensic Pathology of Trauma. New Jersey: Human Press Inc, 2007.

10. Dodd MJ. Pathological Range of Fire: In the Terminal Ballistics. Boca Raton: CRC, 2006; p. 3577.

11. Chadha PV. Catatan Kuliah Ilmu Forensik dan Toksikologi (5th ed). Jakarta: Widya Medika, 1995. 